\title{
Heavy Metals Resistance Potential of Some Aspergillus spp. Isolated from Tannery Wastewater
}

\author{
${ }^{* 1}$ M. Abdullahi, 2D. A. Machido \\ ${ }^{1}$ Department of Microbiology, Usmanu DanFodiyo University, Sokoto, Nigeria. \\ 2Department of Microbiology, Ahmadu Bello University, Zaria.
}

[ ${ }^{*}$ Corresponding Author: E-mail: abdullahi.bilyamin08@yahoo.com; $\left.\mathbf{P}+2348035575720\right]$

\begin{abstract}
Wastewater from three functional tanneries within sokoto metropolis, Nigeria, was investigated to determine the physicochemical properties as well as the distribution of fungal species in the untreated wastewater samples. Samples collected were designated (a-c) representing three sampling points. The isolated fungal species were; Aspergillus niger, Aspergillus flavus, Aspergillus fumigatus, Aspergillus terreus, Aspergillus tamarii and Aspergillus oryzae. Of the fungal species, Aspergillus flavus was the most prevalent (17\%) of the total count on the isolation plate, followed by Aspergillus niger $(12 \%)$ and the least was Aspergillus oryzae. High levels of $\mathrm{pH}(9.6 \pm 1.7-9.9 \pm 1.2)$; electrical conductivity (4656 $\mu \mathrm{s} / \mathrm{cm} \pm 886-5933 \mu \mathrm{s} / \mathrm{cm} \pm 228)$; total dissolved solids (2024 mg/l $\pm 514-2934 \mathrm{mg} / \mathrm{l} \pm 113$ ) and nitrate (88.7 $\mathrm{mg} / \mathrm{I} \pm 2.2-94.7 \mathrm{mg} / \mathrm{I} \pm 4.5$ ) was observed in all the sampling points. The fungal species were screened for their ability to resist and grow in the presence of different concentrations of $\mathrm{Pb}$ (lead), $\mathrm{Cr}$ (chromium) and $\mathrm{Cd}$ (cadmium) in the laboratory. The result revealed that the majority of the isolates were resistant to $\mathrm{Pb}$ and $\mathrm{Cr}$, whereas to $\mathrm{Cd}$, only a few were able to resist and grow. A. niger, A. flavus and $\mathrm{A}$. terreus had the highest level of resistance and tolerance to all the heavy metals, with a strong growth often exceeding the control (PDB without test heavy metals). Therefore, it was concluded that these species of Aspergillus could be performing an essential role in the mycoremediation of these metals present in the tannery wastewater during their period of acclimatization through bioaccumulation.
\end{abstract}

Keywords: Aspergillus sp., Bioaccumulation, Mycoremediation, NESREA.

\section{INTRODUCTION}

The tanning industry is known to be source of pollutions especially through the discharge of effluents that possess organic and inorganic dissolve solids accompanied by propensities for high oxygen demand containing potentially toxic metal residues. A significant part of the chemical used in processing the leather is not actually absorbed in the process but it is discharged into the environment (Durai and Rajasimman, 2011). The quantity of heavy metals released into the environment is on the increase as a result of industrialization and technological advancement (Amini et al., 2008). This is of great concern to environmentalist as most of the metals are toxic, accumulate in food chains and more importantly non-degradable and persistent in nature and exerts a selection pressure on soil micro-biota (Emmanuel et al., 2015).

Lead, chromium and cadmium are included as one of the most detrimental heavy metals because of their high toxicity (Graz et al., 2011;
Salinas et al., 2000).With the sporadic rise in industrial development, diseases and several struggles arising from heavy metal pollution requires safe and effective remediation approach as most if not all of the physiochemical methods of waste treatment are affected with many problems (Ahluwalia and Goyal, 2007). According to Rao et al. (1982) effluents from tanneries are known to have higher concentration of heavy metals. Rabah and Ibrahim (2010) reported high chromium content in soil polluted with tannery wastes in Sokoto.

Fungi are a ubiquitous group of microorganisms found in sub-aerial and subsoil of environments and often become a dominant group of metalrich or metal polluted environments (Gadd, 1990). Today studies have shown that the strains isolated from contaminated area have the potential to tolerate such toxic conditions. Microbes have been shown to have the capacity to survive by adapting at high concentrations of heavy metals (Anahid et al., 
2011; Yuan et al., 2007). Therefore, there is the need to explore newcomer resistant isolates as eco-friendly alternative means of heavy metal removal from tannery wastewater and other industrial effluents.

This research was carried out to isolate fungi from untreated tannery wastewater in Sokoto metropolis and to assess their resistance level towards cadmium, lead and chromium.

\section{MATERIALS AND METHOD}

\section{Sample collection}

Wastewater samples were collected from three functional tanneries: A (Unguwar Rogo I), B (Unguwar Rogo II) and C (Tudun Wada). In all, three samples i.e. one sample from each sampling point was collected in clean plastic containers according to standard procedures (Reza and Singh, 2010).The samples were collected in duplicate by lowering the plastic containers $30 \mathrm{~cm}$ deep into the mixed section of sampling point. All sample containers containing $500 \mathrm{ml}$ of the sample were properly labelled to indicate the sample code, collection point, date and sampling time. After collection, the bodies of the plastic containers were rinsed thoroughly with sterile distilled water before transporting them in ice box to the laboratory for microbiological and the following physicochemical analysis: $\mathrm{pH}$, nitrate, sulphate, phosphate, biological oxygen demand, and oil and grease contents.

\section{Isolation of fungi}

This was done according to method of Ezeonuegbu et al. (2014). Nine (9) millilitres of each sample was transferred into duplicate sterile centrifuge tubes and spun at $250 \mathrm{rpm}$ for $10 \mathrm{~min}$ to concentrate the fungal propagules present in the samples. An equivalent amount of $0.1 \mathrm{ml}$ aliquot of each sample suspensions was spread inoculated on triplicate plates of different freshly prepared solidified media (Potato dextrose agar (PDA) and Potato carrot agar) containing $50 \mathrm{ug} / \mathrm{L}$ of chloramphenicol using a sterile bent glass rod. All plates were incubated aerobically at $28{ }^{\circ} \mathrm{C}$ in disinfected dark cupboard for 7 days and monitoring daily for evidence of fungal colonies.
The fungal colonies observed were distinguished based on their cultural characteristics and recorded as (\%) frequency of occurrence. The distinct colonies were isolated into slants of potato dextrose agar to obtain pure isolates and for further laboratory analysis.

\section{Identification of fungal isolates}

All the fungal isolates obtained from each of the samples were identified based on macromorphological characteristics such as surface colour, texture, elevation, colour of the reverse side, margins and growth was recorded. For the micro-morphological characteristics, a small portion of the growing region was mounted on clean grease free slide with a drop of Lactophenol cotton blue, covered with a cover slip and examined by microscopy using $\times 40$ objective lens. The presence of reproductive structures, septation, conidia and conidiophores were observed and recorded (Samson et al., 1981).

\section{Preparation of stock solution of heavy metals}

Stock solutions of lead nitrate, potassium chromate and cadmium sulphate were prepared by dissolving $0.1 \mathrm{~g}$ of each analytical grade salt in separate conical flask containing $500 \mathrm{ml}$ of distilled water. The flasks were warmed on a hot plate simultaneously with gentle shaking to obtain a clear solution of $200 \mathrm{ug} / \mathrm{ml}$ concentrations and sterilized at $121^{\circ} \mathrm{C}$ for 15 $\min$. The solutions were stored in a refrigerator at $4{ }^{\circ} \mathrm{C}$ until needed.

\section{Screening of fungal isolates for heavy metals resistance}

The fungal isolates were screened for their ability to resist and grow in the presence of 5 , 10 and $15 \mathrm{ug} / \mathrm{ml}$ of the test heavy metals in vitro. The yield of biomass in liquid static cultures was used as index of resistance and growth in the presence of test concentration of the heavy metals (Bennet, et al., 2002; Ezeonuegbu, et al., 2014). Each test isolate was inoculated in duplicate conical flasks containing $50 \mathrm{ml}$ of freshly prepared potato dextrose broth supplemented with different 
concentrations of the test heavy metals. Also, medium inoculated with test isolates without heavy metals was used as controls and for comparative evaluation. The inoculated flasks were incubated at ambient temperature $\left(28^{\circ} \mathrm{C}\right)$ aerobically for 7 days. The mycelia mats produced were harvested by filtration through pre-weighed Whatman filter paper (No. 1) and aluminium foil. The filter paper bearing the mycelia mats was dried in an oven at $70^{\circ} \mathrm{C}$ for 48 hours and re-weighed. The yield of dry mycelia biomass was obtained by subtracting the weight of the filter paper alone from the weight of the filter paper and the mycelia biomass (Bennet, et al., 2002; Ezeonuegbu, et al., 2014).

\section{Data analysis}

Descriptive statistics was used to analyse physicochemical data using Prism software (Graphpad version 16.0).

\section{RESULTS AND DISCUSSION}

As presented in Table 1, the values of temperature in the study sites varies from 20.0 to 23.9 which were within the permissible limit $(<40)$ of NESREA, Nigeria. The lower temperature in this study could be attributed to sampling time and weather condition as at the time of sampling. The Electrical conductivity recorded for the sampling sites range from 4656-5933 $\mathrm{\mu s} / \mathrm{cm}$ and was above the recommended limit $(200 \mu \mathrm{s} / \mathrm{cm})$ of NESREA (2007). The variations observed could be attributed to method of analysis adopted by the researchers and possible difference of the dissolved salts used in the tannery industry. The higher conductivity could pose a threat when discharged into water bodies by altering the chelating properties of the water body and create an imbalance of free metal availability for both flora and fauna (Akan et al., 2008).

The total dissolved solids of the samples analyzed range from 2024 to $2934 \mathrm{mg} / \mathrm{L}$ as presented in Table 1. These values in all sampling sites were higher than the permissible limit $(900 \mathrm{mg} / \mathrm{L})$ of NESREA (2007). The high values recorded in this study might be attributed to high salt content which further renders the tannery wastewater unsuitable for irrigation, suggesting the need for treatment (Goel, 1997; Awofolu et al., 2005). Earlier analysis by Adamu et al., (2015) substantiated this study by reporting values for conductivity (13586-15500 $\mu \mathrm{s} / \mathrm{cm})$ and TDS $(170-943.5 \mathrm{mg} / \mathrm{l})$ that were higher than permissible limit of NESREA (2007) in Sokoto.

The results of this study shows that the levels of $\mathrm{pH}$ range from 9.6 to 9.9. Of the sampling sites, (A) shows a higher $\mathrm{pH}$ value than $(\mathrm{B})$ and $(\mathrm{C})$ which was basic and above the standard value set by NESREA (2007) (6-9). Akan et al. (2008) in Kano and Wosnie and Wondie (2014) from Ethiopia reported values that fell within the permissible limit. The $\mathrm{pH}$ outside permissible limit adversely affects the availability of heavy metal concentration and microorganisms (Akan et al., 2008). The high values in this study might be as a result of lime, soda ash and sodium sulphide used in the hides and skin processing and also due to the presence of carbonates and bicarbonates. The values in this study were similar to the findings of Amanial (2016). Discharge of untreated wastewater with such a high $\mathrm{pH}$ into rivers or on lands for any purpose could be detrimental to soil fauna and aquatic biota (Sugasini and Rajagopal, 2015).

The average dissolved oxygen along the sampling sites range from 5.9-6.6 mg/L and were within the standard permissible limit $(>2.0)$ of NESREA (2007). DO is a measure of the degree of pollution by organic matter. The concentration of DO in water and wastewater is affected by physical, chemical and biological factors. Decomposition of large quantities of organic matter can severely depletes the water of oxygen. The standard for sustaining aquatic life is stipulated at $5 \mathrm{mg} / \mathrm{L}$ a concentration below this value adversely affects aquatic biological life, while concentration below $2 \mathrm{mg} / \mathrm{L}$ may lead to death for most aquatic life forms (Rossi et al., 2015).

The biological oxygen demand $(6.0-8.1 \mathrm{mg} / \mathrm{L})$ and chemical oxygen demand $(7.8-9.0 \mathrm{mg} / \mathrm{L})$ analyzed in this study were within the permissible limits of NESREA indicating a low microbial load. These low values might be 
attributed to the low biodegradable organic and inorganic matter present in the wastewater, which coincides with the fact that the lesser the BOD the higher the dissolved oxygen in any water or wastewater sample. The result in this study shows that the wastewater samples from the study site do not constitute a serious pollution problem with regards to the organic and inorganic matter content and therefore the discharge of wastewater with such a low BOD and COD poses no threat to the survival of aquatic life.

Nitrate concentrations in the sampling sites range from 84.7 to $94.7 \mathrm{mg} / \mathrm{L}$ respectively and were above the permissible limit $(20 \mathrm{mg} / \mathrm{L})$ of NESREA (2007). Nitrate is highly leaching, therefore, excessive rainfall or over-irrigation of soil with untreated wastewater with such a high nitrate content could lead to leaching of nitrate below the plant's root zone and may eventually reach groundwater. In addition, disposal of such wastewater with excessive concentration of nitrates into lakes and streams can cause excessive growth of algae and other plants, leading to accelerated eutrophication of the water bodies and occasional loss of dissolved oxygen (Knepp and Arkin, 2006).

The wastewater samples contained (4.3-5.0 $\mathrm{mg} / \mathrm{L}$ ) oil and grease which was above the permissible limit $(0.1 \mathrm{mg} / \mathrm{L})$ of NESREA respectively. These high values might be attributed to the fact that during leather manufacturing, natural oils and grease is released from within the skin structure. If surface waters are contaminated with grease or thin layers of oil, oxygen transfer from the atmosphere is reduced. If these fatty substances emulgate, they create a very high oxygen demand on account of their biodegradability (Bosnic et al., 1996).

Table 2 presents the mycoflora isolated from the study sites which had a predominance of six (6) fungal species belonging to the genus Aspergillus. This observation strongly indicates that members of this fungal genus have the capacity to survive, adapt and colonize environments polluted with tannery effluent. The difference between the sampled sites regarding their richness in microbial isolates appears to be closely linked to the high level of $\mathrm{pH}$, TDS, and EC. The percentage and frequency of occurrence of fungal isolates (Table 3) was higher in $(B)$ than in $(C)$ and $(A)$ i.e. $B>C>A$ respectively. The source of pollutants as well as long periods of exposure could be among factors regulating fungal stress and adaptation (Zafar et al., 2007). Several reports have shown that organisms in tannery effluent utilize phenols and other hydrocarbons as source of energy (Mythili and Karthikeyan, 2011). The ability of fungi to secret extracellular enzymes in enormous could probably influence their ability to grow on a different hydrocarbon source (Steffen et al., 2003) as well as resist high levels of heavy metals due to their ability to bioconvert (Lubertozzi and Keasling, 2009), bioadsorb (Gorgeevaram et al., 2007; Nilanjana et al., 2008) or bioaccumulate (Lubertozzi and Keasling, 2009) the metal ions.

The results obtained from this study revealed that resistance to the toxicity of $\mathrm{Pb}, \mathrm{Cr}$ and $\mathrm{Cd}$ was common among species of the mycoflora of tannery wastewater under study. At $5 \mu \mathrm{g} / \mathrm{ml}$, $A$. fumigatus, $A$. flavus, $A$. niger and $A$. terreus were the most resistant to $\mathrm{Pb}$ (Fig. 1). $A$. oryzae, $A$. tamarii and $A$. niger were observed to be the most resistant to $\mathrm{Cr}$ at the same concentration. However, $5 \mu \mathrm{g} / \mathrm{ml}$ concentration of $\mathrm{Cd}$ was found to suppress the growth of all the isolates except for $A$. niger and $A$. tamarii. Increasing the concentration of the test metals to $10 \mu \mathrm{g} / \mathrm{ml}$ yielded a different resistant pattern among the isolates to $\mathrm{Pb}, \mathrm{Cr}$ and $\mathrm{Cd}$ (Fig. 2). $A$. niger was observed to be the most resistant to $\mathrm{Pb}$ as well as $\mathrm{Cr}$ at the same concentration. It was also noted that $A$. flavus and $A$. niger were the most resistant to $\mathrm{Cd}$. However, the mean yield of dry biomass was generally lower at $10 \mu \mathrm{g} / \mathrm{ml}$ than at $5 \mu \mathrm{g} / \mathrm{ml}$. Increasing the levels of the test metals to $15 \mu \mathrm{g} / \mathrm{ml}$ resulted in a significant decrease in the biomass yield (Fig. 3) and $\mathrm{Pb}$ was better resisted at this concentration compared to $\mathrm{Cr}$ and $\mathrm{Cd}$. 
Abdullahi and Machido: Heavy Metals Resistance Potential of Some aspergillus sp. Isolated ...

Table 1: Physicochemical Properties of the Wastewater from the three tanneries in Sokoto Metropolis

\begin{tabular}{lllll}
\hline \multirow{2}{*}{$\begin{array}{l}\text { Physicochemical } \\
\text { Parameters }\end{array}$} & \multicolumn{4}{c}{$\begin{array}{l}\text { Sampling } \\
(\mathrm{n}=3)\end{array}$} \\
\cline { 2 - 5 } & $\mathrm{A}$ & $\mathrm{B}$ & $\mathrm{C}$ & $\begin{array}{l}\text { Permissible Limits } \\
\text { NESREA }\end{array}$ \\
\hline $\mathrm{pH}$ & $9.9 \pm 1.2$ & $9.7 \pm 1.5$ & $9.6 \pm 1.7$ & $6.0-9.0$ \\
Temperature & $20.1 \pm 0.9$ & $22.5 \pm 0.7$ & $23.9 \pm 1.3$ & $<40$ \\
Electrical Conductivity $(\mu \mathrm{s} / \mathrm{cm})$ & $5845 \pm 34.0$ & $5933 \pm 228$ & $4656 \pm 886$ & 200 \\
Total Dissolved Solids $(\mathrm{mg} / \mathrm{L})$ & $2893 \pm 16.5$ & $2934 \pm 113$ & $2024 \pm 514$ & 900 \\
Dissolved Oxygen $(\mathrm{mg} / \mathrm{L})$ & $6.6 \pm 1.8$ & $6.0 \pm 1.2$ & $5.9 \pm 1.1$ & $>2.0$ \\
Biological Oxygen Demand $(\mathrm{mg} / \mathrm{L})$ & $8.1 \pm 0.6$ & $6.0 \pm 0.3$ & $7.0 \pm 0.4$ & 30 \\
Chemical Oxygen Demand $(\mathrm{mg} / \mathrm{L})$ & $9.0 \pm 0.7$ & $7.8 \pm 1.1$ & $8.5 \pm 0.9$ & 80 \\
Phosphate $(\mathrm{mg} / \mathrm{L})$ & $0.4 \pm 0.0$ & $0.5 \pm 0.0$ & $0.4 \pm 0.0$ & \\
Nitrate $(\mathrm{mg} / \mathrm{L})$ & $84.7 \pm 2.2$ & $94.7 \pm 4.5$ & $88.5 \pm 8.0$ & 20 \\
Sulphate $(\mathrm{mg} / \mathrm{L})$ & $2.9 \pm 0.4$ & $2.5 \pm 0.4$ & $3.5 \pm 0.5$ & 500 \\
Oil and grease $(\mathrm{mg} / \mathrm{L})$ & $5.0 \pm 0.4$ & $4.3 \pm 0.4$ & $4.7 \pm 0.8$ & 0.1
\end{tabular}

A=Unguwar Rogo I; B=Unguwar Rogo II and C=Tudun Wada 
The ability for the fungi species to survive and grow in the presence of different concentrations of the test heavy metals suggest that they must have developed mechanisms to resist the toxicity of the metals. Several of such mechanisms have been reported to be employed by fungi growing in environments with high concentrations of heavy metals. These include; metal sequestration or accumulation (Teitzel and Mattew, 2003; Nilanjana, et al., 2008) and enzymatic modification of the metal ions to less toxic form (Ramarao et al., 1997). In addition, it has been reported that fungi possess specific genes for resistance to heavy metal ions. Mostly, these genes are chromosomal but others are plasmid borne (Nies, 1999). The plasmid encoded genes are mostly induced by the presence of specific metal ions (Rosen, 2002). These form the basis of bioaccumulation as a mechanism of resistance to heavy metal ions among fungi (Ezeonuegbu, 2014).

The variation in resistance to $\mathrm{Pb}, \mathrm{Cr}$ and $\mathrm{Cd}$ observed among the fungal genera isolated from the studied sites suggest the isolated fungal species differ in their sensivity to different metals (Shazia et al., 2012; Nies and Silver, 1995; Ezeonuegbu, 2014). The observations made in this study strongly suggest most of the isolates tested probably have the potential as candidates in mycoremediation of tannery effluent (Nies and Silver, 1995; Shazia et al., 2012; Thipeswamy et al., 2012) thus, may be selected for use in the treatment of heavy metal contaminated environment.

Table 2: Percentage and Frequency of Occurrence of Fungal genera Isolated from the study sites.

\begin{tabular}{lllll}
\hline Fungal Isolates & \multicolumn{4}{l}{ Sampling Sites (\%) } \\
\hline Aspergillus niger & $\mathrm{A}(\%)$ & $\mathrm{B}(\%)$ & $\mathrm{C}(\%)$ & Total $(\%)$ \\
Aspergillus flavus & $5(35.7)$ & $5(16.7)$ & $5(33.3)$ & $12(25.5)$ \\
Aspergillus fumigatus & $0(0)$ & $1(5.6)$ & $0(0)$ & $1(2.13)$ \\
Aspergillus terreus & $3(21.4)$ & $7(38.9)$ & $0(0)$ & $10(21.28)$ \\
Aspergillus tamarii & $1(7.1)$ & $2(11.1)$ & $3(20)$ & $6(20.9)$ \\
Aspergillus oryzae & $1(7.1)$ & $0(0)$ & $0(0)$ & $1(2.13)$ \\
& & & & \\
\hline Total & $14(28)$ & $18(38.3)$ & $15(31.9)$ & $47(100)$ \\
\hline
\end{tabular}

$\mathrm{A}=$ Unguwar Rogo I, $\mathrm{B}=$ Unguwar Rogo II and $\mathrm{C}=$ Tudun Wada

Values in parenthesis are percentage frequency of occurrence of the fungal isolates.

Table 3: Occurrence of Fungi Isolates in Wastewater Samples from the Study Sites

\begin{tabular}{|c|c|c|c|c|c|c|}
\hline $\begin{array}{l}\text { Sampling } \\
\text { Points }\end{array}$ & Isolates & $\operatorname{er} 0.5 \mathrm{~m}$ & of Sample) & & & \\
\hline & A. niger & $\begin{array}{l}A . \\
\text { flavus }\end{array}$ & $\begin{array}{l}\text { A. } \\
\text { fumigatus }\end{array}$ & $\begin{array}{l}\text { A. } \\
\text { tamarii }\end{array}$ & $\begin{array}{l}A . \\
\text { terreus }\end{array}$ & $\begin{array}{l}\text { A. } \\
\text { oryzae }\end{array}$ \\
\hline$A$ & $(++)$ & $(+++)$ & - & $(+)$ & $(++)$ & $(+)$ \\
\hline$B$ & $(+++)$ & $(+++)$ & $(+)$ & $(++)$ & $(+++)$ & - \\
\hline C & $(+++)$ & $(+++)$ & - & $(++)$ & - & - \\
\hline
\end{tabular}

$(+++)=$ High $(++)=$ Moderate $(+)=$ Low $(-)=$ No growth 
Abdullahi and Machido: Heavy Metals Resistance Potential of Some aspergillus sp. Isolated ...

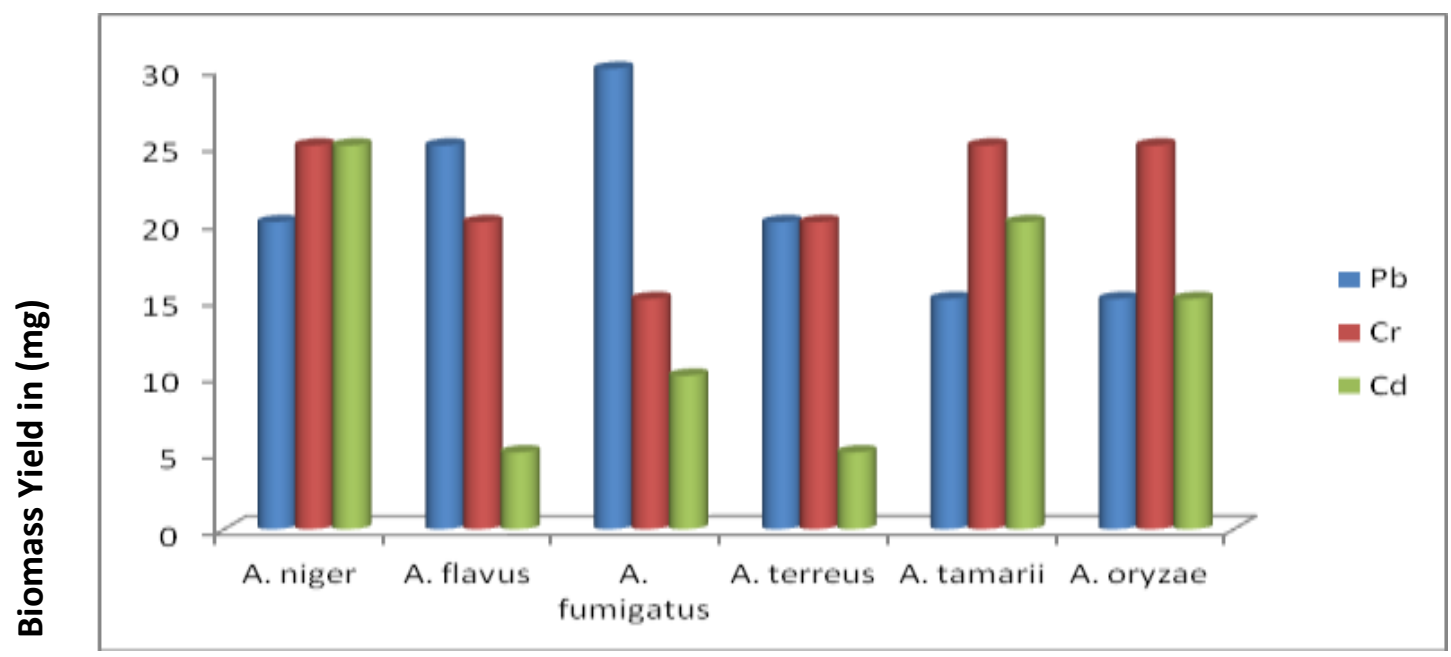

Figure 1: Mean Biomass Yield of the Test Fungal Isolates to $5 \mu \mathrm{g} / \mathrm{ml}$ of Heavy Metals

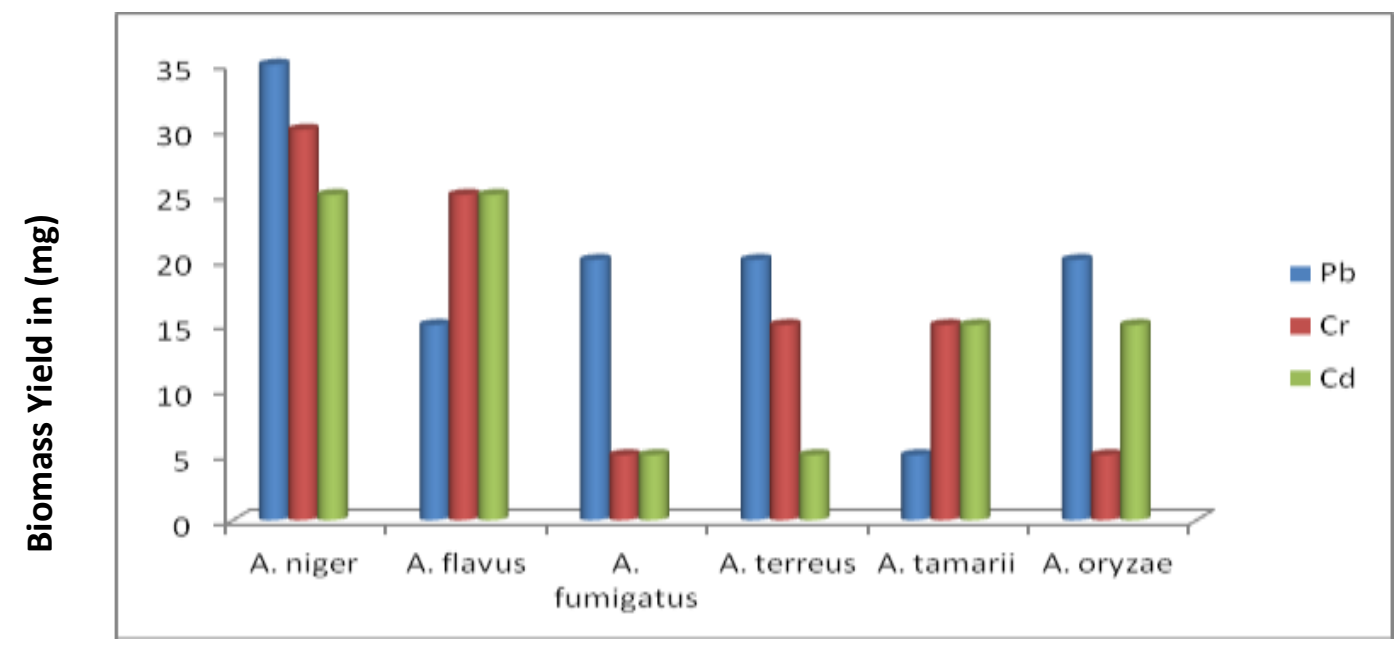

Figure 2: Mean Biomass Yield of the Test Fungal isolates to $10 \mu \mathrm{g} / \mathrm{ml}$ of Heavy Metals

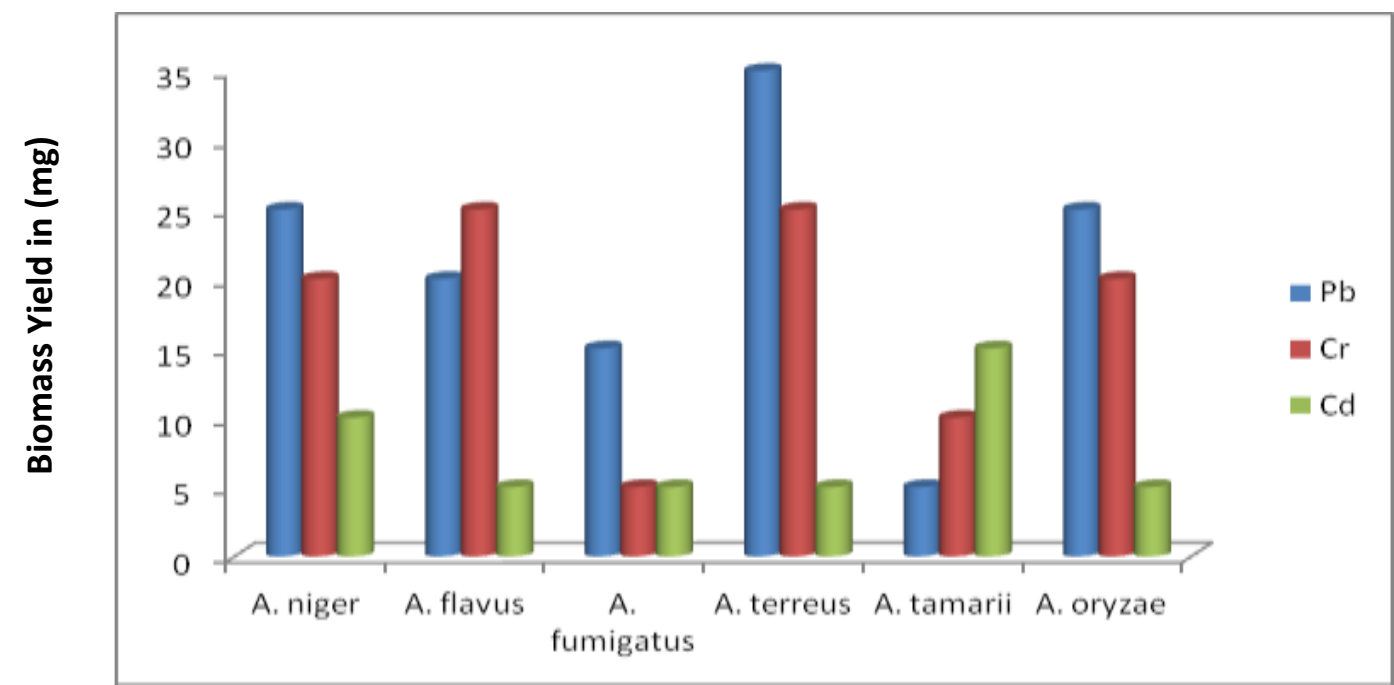

Figure 3: Mean Biomass Yield of the Test Fungal isolates to $15 \mu \mathrm{g} / \mathrm{ml}$ of Heavy Metals 


\section{CONCLUSION}

The physicochemical quality of the wastewater and other pollutants causes variation in fungal population in the different samples analysed. $A$. niger, $A$. terreus and $A$. flavus were the most resistant to $\mathrm{Pb}$ and $\mathrm{Cr}$ while $\mathrm{Cd}$ was the least resisted by all the fungal species at $15 \mu \mathrm{g} / \mathrm{ml}$ concentration. The fungal species identified could possibly be useful in bioremediation of toxic pollutants as well as biosorption and bioaccumulation of toxic heavy metals.

\section{ACKNOWLEDGEMENT}

The author appreciates the assistance rendered by Malam Abdulrahman of General Biology Laboratory Botany Unit, Usmanu Danfodiyo University Sokoto, for his assistance during the identification of the fungal isolates.

\section{REFERENCES}

Adamu, A., ljah U.J.J., Ibrahim, M., Isamil, Y.H. and Ibrahim, U.B. (2015). Isolation of Biosurfactant producing bacteria from tannery effluents in Sokoto Metrolpolis, Nigeria. Internatial Journal of Innovative Science and Engineering Technology, 2(1):366-73.

Ahluwalia, S.S. and Goyal, D. (2007). Microbial and Plant derived Biomassfor the removal of Heavy Metals from Wastewater. Bioresource Technology, 98: 2243-2257

Akan, J.C., Abdulrahman, F.I., Dimari, G.A. and Ogugbuaja, V.O. (2008). Physicochemical determination of pollutants in wastewater and vegetable samples along the Jakara wastewater channel in Kano Metropolis, Kano State, Nigeria. European Journal Scientific Research 23:122-133.

Amanial, H.R. (2016). Physicochemical characterization of Tannery effluent and its impact on the nearby river. Open Access Library Journal, 3: e2427. http://dx.doi.org/10.4236/oalib.1102427.

Amini, M., Younesi, H., Bahraniifar, N., Akbar, A., Lorestani, Z., Ghorbani, F., Daneshi, A. and Sharifzadeh, M. (2008). Application of Response surface methodology for optimization of lead biosorption in an aqueous solution by Aspergillus niger. Hazardous Materials, 154: 694-699
Anahid, S., Yaghmaei, S. and Ghobadinejad, Z. (2011). Heavy metals tolerance of fungi. Scientia Iranica, 18: 502-8

Awofolu, O.R., Mbolekwa, Z., Mtshemla, V. and Fatoki, O.S. (2005). Levels of Trace metals in water and sediments of Tyume River and Its Effect on the Irrigated Farmland. Journal of Water Sanitation, 31: 87-94.

Bennet, J.W., Wunch, K.G. and Faison, B.D. (2002). Use of fungi in biodegradation: of fungi in bioremediation. In: Manual of Environmental Microbiology, Washington D.C.: ASM Press, 960-971pp.

Bosnic, M., Buljan, J. and Daniels, R. (1996). Pollutants in Tannery Effluents. Definitions and Environmental Impact, Limits for Discharge into Water Bodies and Sewers. UNIDO. Regional Programme for Pollution Control in the Tanning Industry in South-East Asia. US/RAS/92/120.

Durai, G. and Rajasimman, M. (2011).

Biological Treatment of Tannery Wastewater- A Review. Journal of Environmental science and Technology, 4(1), 1-17.

Emmanuel, S. D., Adamu, I. K., Ejila, A., Ja'afaru, M. I., Amos, Y., Abubakar, M. and Agbor, O. (2015). Biosorption of hexavalent chromium (chromium (VI) ion from industrial tannery effluent using filamentous fungi on modified rice husk medium/potato dextrose medium (MRHM/PDM). African Journal of Biotechnology, 14(13), 1143-1150.

Ezeonuegbu, B.A., Machido, D.A. and Yakubu, S.E. (2014). Composition of fungal flora in raw refinery effluent, effluent retention pond and a treated effluent recipient river. Journal of Applied Science Environmental Management, 18(4): 592-596

Gad, G. (1990). Metal tolerance: Microbiology of extreme environments. Milton Keynes: open university press, pp. 178-210

Goel, P.K. 1997. Water pollution, causes, effects and control. New Age International (P) Ltd., publishers, New Delhi, 269.

Gorgeevaram, S., Dhanarani, S., Park, J., Dexillin, M. and Thamaraiseli, K. (2007). Biosorption of chromium and nickel by heavy metal resistant fungal and bacterial isolates. Journal of Hazardous Materials, 146: 270-277. 
Graz, M., Pawlikowska Pawlega, B. and Jarosz-Wilkolaska, A. (2011). Growth inhibiton and intracellular distribution of the white-rot fungus Abortiporus biennis. International Journal of Biodeteriatio and Biodegradatio, 65: 124-9

Knepp, G.L. and Arkin, F. (2006). Ammonia Toxicity Levels and Nitrate Tolerance of Channel Catfish. The Progressive FishCulturist, 35:221. http://www.epa.gov/waterscience/standards. Lubertozzi, D. and Keasling, J.D. (2009). Developing Aspergillus as a host for heterologous expression. Biotechnology Advances, 27: 53-75.

Mythili, K. and Karthikeyan, B. (2011). Bioremediation of tannery effluent and its impact on seed germination. Current Botany, 2(8): 40-45.

NESREA, 2007, National Environmental Standards and Regulations Enforcement Agency(Establishment) Act, 2007 A635-655., Federal Republic of Nigeria Official Gazette N0.92 Lagos - 31st July, 2007 Vol.94, Printed and Published by The Federal Government Printer, Lagos,NigeriaFGP125/82007/1,000(0L90)

Nies, D. and Silver, S. (1995). Ion efflux systems involved in bacterial metal resistances. Journal of Indian Microbiology, 14: 186-199

Nies, D.H. (1999). Microbial heavy metal resistance. Applied Microbiology and Biotechnology, 14: 186-199

Nilanjana, D., Vimla, R. nd Karthika, K. (2008). Biosorption of Heavy Metal- An Overview. Indian Journal of Biotechnology, 7: 159-169.

Rabah, A.B. and Ibrahim, M.L. (2010). Physicchemical and Microbiological characterization of soils laden with tannery effluents in Sokoto, Nigeria. Nigerian Journal of Basic and Applied Science, 18 (1): 65-71

Ramarao, V.S., Akthar, N. and Maruthi Mohan, P. (1997). Isolation of a Cadmium tolerant Curvularia sp. From Polluted effluents. Current Science, 73: 453-459

Rao, M.G. and Kumer, N.V.N. (1982). The tannery industrial effluent effect on succinate dehydrogenase activity pattern in a fresh freshwater snail, Pila globosa. Proceeding: Animal Science, 91: 427-431
Reza, R. and Singh, G. (2010). Heavy metal contamination and its indexing approach for the river water. International Journal of environmental Science and Technology, 7: 785-792

Rosen, B.P. (2002). Transport and Detoxification systems for transition metals, heavy metals and metalloids in eukaryotic and prokaryotic microbes. Comparative Biochemistry and Physiology part A: Molecular Integrated Physiology, 133: 689-93

Rossi, F., Motta, O., Proto, A. and Vigliotta, G. (2015). Nitrate removal from wastewater through biological denitrification with OGA 24 in a Batch reactor. Water, 7: 51-62

Salinas, E., Elorzade Orellano, M., Rezza, I., Martinez, L., Marchevsky, E. and Sanz de Tosetti, M. (2000). Removal of cadmium and lead from dilute aqueous solutions by Rhodotorula rubra. Bioresource Technology, 72: $107-12$

Samson, R.A., Hoekstra, E.S. and Van Oorschot, C.A. (1981). Introduction to foodborne fungi. 3rd Ed. Centraalbureau voor Schimmelcultures,pp. 46-85. ISBN 90-7035116-1

Shazia, I., Amara, A. and Kousar, P. (2012). Tolerance Potential of Fungi Isolated from Polluted Soil of Multan, Pakistan. Journal of Biodiversity and Environmental Sciences, 2(10): $27-34$

Steffen, K.T., Hatakka, A. and Hofrichter, M. (2003). Degradation of Benzopyrene by liter decomposing basiodiomycete Stropharia coronilla: Role of manganese peroxidase. Applied and Environmental Microbiology, 69(7): 3957-3964.

Sugasini, A. and Rajagopal, K. (2015). Characterization of Physicochemical Parameters and Heavy Metal Analysis of Tannery Effluent. International Journal of Current Applied Sciences., 4(9): 349-59

Thipeswamy, B., Shivakumar, C.K. and Krishapa, M. (2012). Bioaccumulation potential of Aspergillus niger and Aspergillus flavus for heavy metal removal from paper mill effluent. Journal of Environmental Biology, 33: 10631068

Tietzel, M. and Mattew, R. (2003). Heavy metal resistance of biofilm and planktonic Psalovours 
Nigerian Journal of Basic and Applied Science (June, 2017), 25(1): 120-129

aerbginoser. Applied Environmental Microbiology, 69: 2313-2319

Wosnie, A. and Wondie, A. (2014). Assessment of downstream impact of Bahir Dar Tannery effluent on the head of Blue Nile using macroinvertebrates as Bioindicators. International Journal of Biodiversity and Conservation, 6(4); 342-350. Doi: 10.5897/IJBC2013.0646.

Yuan, H., Li, Z., Ying, J. and Wang, E. (2007). Cadmium (II) removal by a hyperaccumulator fungus Phoma sp. F2 isolated from blende soil. Current microbiology, 55(3), 223.

Zafar, S., Aqil, F. and Ahmad, I. (2007). Metal tolerance and biosorption potential of filamentous fungi isolated from metal contaminated agricultural soil. Bioresource Technology, 98:2557-2561. 